\title{
Variation in Tupi languages: Genealogy, language change, and typology
}

Wolf Dietrich

Universität Münster, Germany

Sebastian Drude

Max Planck Institute of Psycholinguistics

Nijmegen, the Netherlands

At least 40 spoken languages form the large Tupi family in its subfamilies Tupi-Guaraní, Mawé, Aweti, Arikém, Juruna, Mondé, Tupari, Mundurukú, Ramarama and Puruborá, providing a wealth of data for linguistic studies about variation - variation explained by genetic relations (common origin, ultimately from the presumed language 'proto-Tupi') or by contact relations with other indigenous or non-indigenous languages. The interest in indigenous languages has increased in recent years, evinced by the publication of a growing number of descriptive, historical-comparative and other studies.

Most studies published in this volume originate from a linguistic symposium organized by Wolf Dietrich and Sebastian Drude at the $54^{\text {th }}$ International Congress of Americanists in Vienna, in 2012. The symposium was dedicated to "Historical variation and variation by contact among the Tupian languages". Those studies that deal with problems of linguistic genealogy, genetics, language change, and syntactic typology across several Tupi languages or a single Tupi language are published in this special "dossier".

The first six papers deal with problems of the whole Tupi family or at least one of its sub-families. Three of them investigate evolutionary topics; three are cross-linguistic synchronic studies.

Eduardo dos Santos and colleagues from the area of human genetics, in their paper "Origins and demographic dynamics of Tupi expansion: a genetic tale", use recent genetic data in order to show that the Madeira-Guaporé Region may indeed be considered to be the Tupi homeland. Ancient Tupi expansion within the Madeira-Guaporé Region and dispersion to other South American areas seems to be related to patrilocal practices. This outcome allows for new interpretations of archaeological and linguistic data, for instance the dispersion of female associated technologies like ceramics and terminologies related to ceramics.

Ana Vilacy Galucio and colleagues from the Tupi Comparative Project, in their paper "On the genetic relationship and degree of relatedness with the Tupi linguistic family", present the first lexicostatistical and phylogenetic attempt of the genetic classification of most languages of the Tupi family, including four languages of the Tupi-Guarani branch. Based on all relevant previous studies of particular branches of the family, and applying lexicostatistics to a semantically based word list, , the article demonstrates that the two major branches of the State of Rondônia, Mondé and Tuparí, have high percentages of shared cognates. This supports the results of the first article of this volume.

The paper by Sérgio Meira and Sebastian Drude gives an overview of their reconstruction of the segmental phonology of Proto-Maweti-Guarani, the hypothetical proto-language from which modern Mawé, Aweti, and the

DIETRICH, Wolf; DRUDE, Sebastian. Prefácio. Boletim do Museu Paraense Emílio Goeldi. Ciências Humanas, v. 10, n. 2, p. $213-215$. maio-ago. 2015. DOI: http://dx.doi.org/10.1590/1981-81222015000200002.

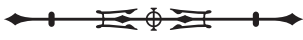


Tupi-Guaraní branch have evolved. The authors discuss other claims made about Proto-Mawetí-Guaraní, contesting, for instance, the often proposed 'relational prefixes' which they attribute to stems beginning in */t/. The paper is a further step to definitely establish the existence of Proto-Maweti-Guarani and to show its usefulness for explaining the evolution of this branch of the Tupi family.

Rik van Gijn, Fernanda Nogueira, and Ana Vilacy Galucio present subordination strategies in ten languages, representing seven branches of the Tupi family. Nominalizations are contrasted with four different verbal strategies of subordination and with affixing. This synchronic study allows for far-reaching historical insights: nominalizations are used for relative and object clauses whereas adverbials are expressed rather by biclausal structures, which tend to be grammaticalized into tight $\mathrm{V}-\mathrm{V}$ constructions and finally affixes. The comparison of typological features of the Tupi family such as subordination leads to groupings different from those obtained by comparative studies of lexicon and phonology.

The subject of the next two papers is verbal argument marking. First, Joshua Birchall's paper on a comparison of verbal argument marking represents one more example of a synchronic comparative study of 16 Tupi languages allowing for new diachronic insights. Twenty years ago a comprehensive study of such dimensions would have been impossible, which is true for most of the papers of this volume. Birchall is particularly interested in the developments that took place in the person marking system of Tupi verbs where apparently the Rondônian branches tended to maintain the absolutive $(\mathrm{S} / \mathrm{O})$ marking pattern on the predicate whereas the system began to change in the "expansionist" branches that spread outwards from Rondônia.

Subsequently Françoise Rose, in her paper on the Tupi-Guarani hierarchical indexing systems, studies the encoding of arguments on transitive verbs in 28 Tupi-Guarani languages showing that the individual Tupi-Guarani languages are much more divergent from each other in their morphosyntax than was assumed before. One of the main outcomes of the study is that the supposed hierarchy $1>2>3$ does not hold for 23 of the 28 languages. The author argues that $1,2>3$ could be a symptom of the more general distinction between SAPs and third person. As in other cases in this volume, the systematic investigation of a great number of languages allows for important new insights.

The following four papers, though dedicated to the study of a single Tupi-Guarani language, are welcome contributions to research of "Variation in Tupi languages" because they offer new data of understudied or even poorly documented languages as well as new analyses of those languages. All these typological studies also are or explicitly historical investigations or include diachronic perspectives.

Two papers of this group deal with Aché, formerly also known as Guayaki, a Tupi-Guarani language (subgroup I) of Paraguay, which is rather distinct in its morphosyntax with regard to most other languages of the branch. Eva-Maria Rößler's paper "Inflectional Morphology Restructuring in Aché" examines grammar change displayed within the "strongly restricted amount of morphological devices encoding inflection in Aché". The retention of Tupi-Guarani morphemes in Aché concerns suffixation whereas the language underwent a dramatic loss of prefixes. Restructuring of Aché grammar occurred by partial or full lexicalization of original TG suffixes.

Wolf Dietrich offers about 200 Aché cognates of Tupi-Guarani lexemes, pronouns and grammatical words, listing cognates in a maximum of 21 TG languages. Comparing the phonological and morphological shape of the Aché cognates, the author is able to show that Aché is indeed a member of Tupi-Guarani subgroup I, though with significant semantic restructuring. In order to elaborate a historical phonology of the Aché language, the author compares the phonological systems of classical Guarani and Mbyá with modern Aché, showing the retentions and the changes that must have

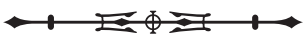


occurred. Aché, in its phonology and lexicon, is close to the neighboring Tupi-Guarani language Mbyá, though Aché seems to have borrowed lexemes from the Yuki-Siriono cluster and from Classical and modern Paraguayan Guarani, too.

In her paper "The rise of number agreement in Nheengatu" Aline da Cruz points out the emergence of the number agreement system of this Tupi-Guarani language spoken in the Upper Rio Negro region, Brazil. The author, combining grammaticalization theories with the examination of the stages of grammaticalization from original Tupinambá to present-day Nheengatu, explains the change from a language without number distinction to a first intermediate stage when plural words occasionally marked plural and then developed into bound morphology. This development may be explained by contact with Portuguese.

In their paper on the sociolinguistics, description, and classification of Jorá Swintha Danielsen and Noé Gasparini investigate for the first time this Tupi-Guarani language of the Beni department, Bolivia. The Jora language, of which only few rememberers are left, had never been studied according to linguistic methods and could not be classified before. The authors evaluate all the existing ethnographic and linguistic data, discovering cognates and comparing phonological and morphological characteristics with those of the neighboring Tupi-Guarani languages (Siriono, Yuki, Guarayo, Bolivian Guarani), and with Baure (Arawak). They come to the conclusion that Jorá is a member of the Sirionoid subgroup of Tupi-Guarani subgroup II.

As a whole, the volume vividly attests the considerable progress of Tupi studies within the last decade. It gives an overview of the state of the art of, and makes valuable contributions to, the study of Tupi languages, especially of their variation and change. 